\title{
Structure and Bonding in Metal Sulphites
}

\author{
PEDER KIERKEGAARD, LARS OLOF LARSSON and \\ BIRGIT NYBERG* \\ Institute of Inorganic and Physical Chemistry, University of Stockholm, \\ S-10405 Stockholm 50, Sweden
}

\begin{abstract}
The variation of the $\mathrm{S}-\mathrm{O}$ distance observed in accurate crystal structure studies of several sulphites is discussed in terms of the bonding character and structural environment of the sulphite group.
\end{abstract}

The results of crystal structure investigations of several metal sulphites 1 conducted at this Institute have been communicated in this periodical. ${ }^{1-4}$ The present paper represents a general discussion of our results and those of other authors.

Knowledge of the structural chemistry of the metal sulphites and of the geometry of the sulphite ion was long rather fragmentary and approximate. The early study by Zachariasen and Buckley ${ }^{5}$ (1931) on sodium sulphite was for a long time the only work in this field. The interpretation of their data was, however, severely hampered by the twin character of the crystals used and the need for a redetermination of this structure has been pointed out by Wells ${ }^{6}$ and others.

The dimensions of the sulphite group, found in recent studies on various metal sulphites, of the sulphate ion, and of a sulphite derivative are collected in Table 1; the bond distances within the sulphite groups have in most cases estimated standard deviations of the order of a hundredth of an Angström unit. The $\mathrm{S}-\mathrm{O}$ distances are seen to be substantially longer than the value $\left(\begin{array}{ll}1.39 & \AA\end{array}\right)$ reported by Zachariasen and Buckley. ${ }^{5}$ On the other hand the theoretical value, $1.54 \AA$, suggested by Gillespie and Robinson ${ }^{7}$ and Robinson ${ }^{8}$ from a proposed relationship between bond lengths and stretching frequencies is somewhat longer than the distances listed in Table 1.

The structural investigation of sodium sulphite ${ }^{3}$ referred to in Table 1 is based upon diffractometer data measured from a twinned crystal. Allowance was, however, made for the influence of the twin character on the X-ray data. The space group is $P \overline{3}$ and the sulphite ion has three-fold symmetry. The

\footnotetext{
* Present address: Institute of Technology, Chemical Centre, Department of Inorganic Chemistry, Box 740, S-220 07 Lund 7, Sweden.
} 


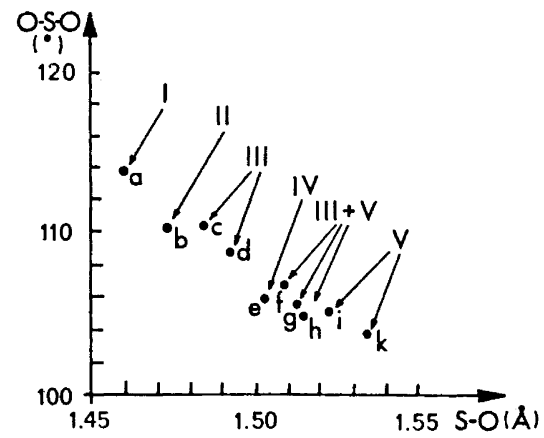

Fig. 1. $\mathrm{S}-\mathrm{O}$ distances plotted against $\mathrm{O}-\mathrm{S}-\mathrm{O}$ angles for various sulphur-oxygen compounds. The compounds are: (a) $\mathrm{K}_{2}\left[\mathrm{CH}_{2}\right.$. $\left.\left(\mathrm{SO}_{3}\right)_{2}\right]$; (b) $\mathrm{Li}_{2} \mathrm{SO}_{4} \cdot \mathrm{H}_{2} \mathrm{O}$; (c) $\mathrm{Co}(\mathrm{en})_{2} \mathrm{SO}_{3} \cdot \mathrm{NCS}$. $2 \mathrm{H}_{2} \mathrm{O}$; (d) $\mathrm{PdSO}_{3}\left(\mathrm{NH}_{3}\right)_{3}$; (e) $\mathrm{Na}_{2} \mathrm{SO}_{3}$; (f) $\mathrm{Cu}_{2}{ }^{\mathrm{I}} \mathrm{Cu}^{\mathrm{II}}\left(\mathrm{SO}_{3}\right)_{2} .2 \mathrm{H}_{2} \mathrm{O}$; (g) $\mathrm{NH}_{4} \mathrm{CuSO}_{3}$; (h) $\mathrm{Ag}_{2} \mathrm{SO}_{3}$; (i) $\left(\mathrm{NH}_{4}\right)_{2} \mathrm{SO}_{3} \cdot \mathrm{H}_{2} \mathrm{O}$; (k) $\mathrm{NiSO}_{3}$. $6 \mathrm{H}_{2} \mathrm{O}$.

The notation $\mathrm{I}-\mathrm{V}$ refers to different types of coordination shown in Fig. 3 .

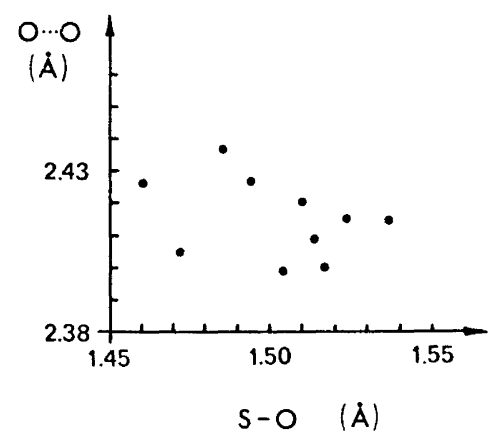

Fig. 2. S-O distances plotted against $\mathrm{O} \cdots \mathrm{O}$ distances for various sulphur-oxygen compounds.

$\mathrm{S}-\mathrm{O}$ distance $1.504 \pm 3 \AA$ may be regarded as a normal value for the sulphite group in a compound of ionic character. This value is rather intermediary in the series of distances listed in Table 1. The $\mathrm{O}-\mathrm{S}-\mathrm{O}$ angles of the various compounds vary in a rather regular way with the $\mathrm{S}-\mathrm{O}$ distances as illustrated in Fig. 1. The decrease of angle with increasing $\mathrm{S}-\mathrm{O}$ distances is such as to yield almost constant $\mathrm{O}-\mathrm{O}$ distances in the $\mathrm{SO}_{3}$ pyramids as illustrated in Fig. 2. These distances, also given in Table 1, are very nearly those reported for the sulphate ion ${ }^{9,10}$ and also for various sulphite derivatives.

The differences among the $\mathrm{S}-\mathrm{O}$ bond lengths may arise from effects upon the $\mathrm{S}$ as well as on the $\mathrm{O}$ atom. The effect on the $\mathrm{S}-\mathrm{O}$ distances, attributable to the S atom, arises from bonding of its lone or "fourth" electron pair to a metal atom as in several sulphites, or to non-metal atoms as in the sulphate ion and several sulphite derivatives. According to Cruickshank, ${ }^{11}$ two strong $\pi$ bonding orbitals are formed with $3 d$ orbitals of sulphur and $2 p$ orbitals of

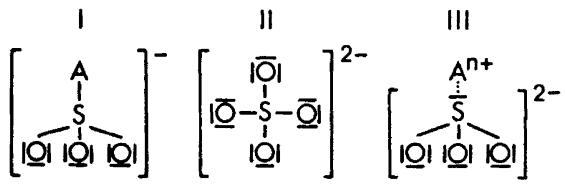

Fig. 3. Different types of coordination in $\mathrm{S}-\mathrm{O}$ compounds. $A$ represents metal ion or carbon. $X$ represents oxygen or nitrogen

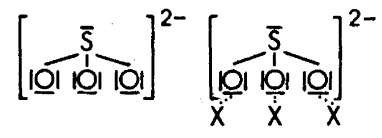
or metal ion.

IV 
Table 1. Bond lengths and angles in various $\mathrm{SO}_{n}{ }^{2-}$ groups $(n=3$ or 4$)$. The estimated within the $\mathrm{SO}_{3}{ }^{2-}$ groups). All values are uncorrected for vibrational motion. $A$ stands are given

\begin{tabular}{|c|c|c|c|c|}
\hline Compound & $\begin{array}{l}\text { Space } \\
\text { group }\end{array}$ & $\begin{array}{c}S_{-O} O \\
(\AA)\end{array}$ & $\begin{array}{c}O-S \\
\left({ }^{\circ}\right)\end{array}$ & $\begin{array}{c}\mathrm{O}-\mathrm{O} \\
(\AA)\end{array}$ \\
\hline $\mathrm{Na}_{3} \mathrm{SO}_{3}$ & $P \overline{\mathbf{3}}$ & $1.504(3)$ & $105.7(2)$ & $2.397(6)$ \\
\hline$\left(\mathrm{NH}_{4}\right)_{2} \mathrm{SO}_{3} \cdot \mathrm{H}_{2} \mathrm{O}$ & $P_{2} / c$ & $\begin{array}{c}1.528(6) \\
1.513(6) \\
1.532(6) \\
A v .1 .524\end{array}$ & $\begin{array}{c}105.4(4) \\
104.4(4) \\
104.6(4) \\
A v .104 .8\end{array}$ & $\begin{array}{c}2.418(8) \\
2.418(8) \\
2.408(8) \\
A v .2 .415\end{array}$ \\
\hline $\mathrm{NiSO}_{3} \cdot 6 \mathrm{H}_{2} \mathrm{O}$ & $R 3$ & $1.536(7)$ & $103.6(6)$ & $2.414(8)$ \\
\hline $\mathrm{Ag}_{2} \mathrm{SO}_{3}$ & $P 2_{1} / c$ & $\begin{array}{c}1.504(22) \\
1.512(27) \\
1.533(23) \\
A v .1 .516\end{array}$ & $\begin{array}{c}106.8(1.2) \\
105.5(1.4) \\
101.6(1.4) \\
A v .104 .6\end{array}$ & $\begin{array}{c}2.400(34) \\
2.438(30) \\
2.360(35) \\
A v .2 .399\end{array}$ \\
\hline $\mathrm{NH}_{4} \mathrm{CuSO}_{3}$ & $R \overline{3} m$ & $1.514(12)$ & $105.3(7)$ & $2.408(16)$ \\
\hline $\mathrm{Cu}_{2}{ }^{\mathrm{I}} \mathrm{Cu}^{\mathrm{II}}\left(\mathrm{SO}_{3}\right)_{2} \cdot 2 \mathrm{H}_{2} \mathrm{O}$ & $P 2_{1} / n$ & $\begin{array}{c}1.515(17) \\
1.509(17) \\
1.505(16) \\
A v .1 .510\end{array}$ & $\begin{array}{c}109.0(1.0) \\
105.4(1.0) \\
105.3(1.0) \\
A v .106 .6\end{array}$ & $\begin{array}{l}2.396(22) \\
2.458(22) \\
2.405(22) \\
A v .2 .420\end{array}$ \\
\hline $\mathrm{PdSO}_{3}\left(\mathrm{NH}_{3}\right)_{3}$ & $P 2_{1} / c$ & $\begin{array}{c}1.480(19) \\
1.488(16) \\
1.515(19) \\
A v .1 .494\end{array}$ & $\begin{array}{c}110.3(1.1) \\
107.6(1.1) \\
107.9(1.1) \\
A v .108 .6\end{array}$ & $\begin{array}{c}2.458(28) \\
2.395(27) \\
2.429(23) \\
A v .2 .427\end{array}$ \\
\hline $\mathrm{Co}(\mathrm{en})_{2} \mathrm{SO}_{3} \cdot \mathrm{NCS} 2 \mathrm{H}_{3} \mathrm{O}$ & $P 2_{1} / c$ & $\begin{array}{c}1.482(15) \\
1.487(15) \\
1.487(15) \\
A v .1 .485\end{array}$ & $\begin{array}{c}109.9(9) \\
110.6(9) \\
110.3(9) \\
A v .110 .3\end{array}$ & $\begin{array}{c}2.430(22) \\
2.441(23) \\
2.441(22) \\
A v .2 .437\end{array}$ \\
\hline $\mathrm{K}_{2}\left[\mathrm{CH}_{2}\left(\mathrm{SO}_{3}\right)_{2}\right]$ & $C 2 / c$ & $\begin{array}{c}1.470(9) \\
1.448(8) \\
1.467(9) \\
A v .1 .461\end{array}$ & $\begin{array}{c}113.8(5) \\
112.8(5) \\
113.2(5) \\
A v .113 .5\end{array}$ & $\begin{array}{c}2.424(12) \\
2.432(12) \\
2.421(12) \\
A v .2 .426\end{array}$ \\
\hline $\mathrm{Li}_{2} \mathrm{SO}_{4} \cdot \mathrm{H}_{2} \mathrm{O}$ & $P 2_{1}$ & $\begin{array}{c}1.462(2) \\
1.482(2) \\
1.479(2) \\
1.466(2) \\
A v .1 .472\end{array}$ & $\begin{array}{c}109.2(1) \\
110.0(1) \\
110.9(1) \\
108.4(1) \\
109.1(1) \\
109.1(1) \\
A v .109 .4\end{array}$ & $\begin{array}{l}2.400(3) \\
2.409(3) \\
2.412(3) \\
2.401(3) \\
2.400(3) \\
2.399(3) \\
A v .2 .404\end{array}$ \\
\hline
\end{tabular}

oxygen. In the $\mathrm{SO}_{4}{ }^{2-}$ ion, these $\pi$ bonds will increase the bonding strength, and the $\mathrm{S}-\mathrm{O}$ bond distances will decrease from the value calculated for an $\mathrm{S}-\mathrm{O}$ single bond, $1.69 \AA^{11}$ to $1.47 \AA^{9,10}$ The effect of different types of coordination around the $\mathrm{SO}_{3}$ group is an important consideration with respect to the $\mathrm{S}-\mathrm{O}$ distances. 
standard deviations $( \pm \sigma)$ are given in brackets as units of the last decimal place (only for metal ion or carbon. $X$ stands for oxygen or nitrogen. $O \ldots(\mathrm{H})-\mathrm{N}$ distances in brackets.

\begin{tabular}{|c|c|c|c|c|c|}
\hline $\begin{array}{c}\mathrm{O}-\mathrm{Me} \\
(\AA)\end{array}$ & $\begin{array}{l}\text { Nos. of } \\
\text { Me lig. }\end{array}$ & $\begin{array}{c}0 \cdots(\mathrm{H})-X \\
(\AA)\end{array}$ & $\begin{array}{c}\text { Nos. of } \\
\mathrm{X} \text { lig. }\end{array}$ & $\begin{array}{c}A-S \\
(\AA)\end{array}$ & Ref. \\
\hline Av. 2.42 & 3 & & - & - & 3 \\
\hline $\bar{z}$ & $\underline{-}$ & $\begin{array}{l}2.77 \text { (Av. 2.85) } \\
2.78 \text { (Av. 2.83) } \\
\text { (Av. 2.84) }\end{array}$ & $\begin{array}{l}3 \\
3 \\
3\end{array}$ & - & 15 \\
\hline - & - & Av. 2.70 & 3 & - & 14 \\
\hline $\begin{array}{l}\text { Av. } 2.47 \\
\text { Av. } 2.38 \\
\text { Av. } 2.32\end{array}$ & $\begin{array}{l}2 \\
2 \\
2\end{array}$ & $\underline{-}$ & $\overline{-}$ & 2.47 & 4 \\
\hline 2.12 & 1 & (Av. 2.97) & 2 & 2.15 & 1 \\
\hline $\begin{array}{r}2.13 \\
\text { Av. } 2.09 \\
2.11\end{array}$ & $\begin{array}{l}1 \\
2 \\
1\end{array}$ & $\begin{array}{l}2.65,2.93 \text { Av. } 2.84 \\
2.77 \\
2.91\end{array}$ & $\begin{array}{l}2 \\
1 \\
1\end{array}$ & 2.14 & 2 \\
\hline$\overline{-}$ & $\overline{-}$ & $\begin{array}{l}\text { (Av. 2.99) } \\
\text { (Av. 3.10) } \\
(\text { Av. 2.96) }\end{array}$ & $\begin{array}{l}4 \\
2 \\
3\end{array}$ & 2.25 & 16 \\
\hline 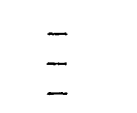 & $=$ & $\begin{array}{ll}2.75 & (2.88) \\
2.84 & (2.84) \\
& (\text { Av. 2.99) }\end{array}$ & $\begin{array}{l}2 \\
2 \\
2\end{array}$ & 2.20 & 17 \\
\hline $\begin{array}{l}\text { Av. } 2.81 \\
\text { Av. } 3.19 \\
\text { Av. } 2.88\end{array}$ & $\begin{array}{l}4 \\
3 \\
2\end{array}$ & $\underline{-}$ & $\underline{-}$ & 1.77 & 12 \\
\hline $\begin{array}{l}1.92 \\
1.94 \\
1.96 \\
1.98\end{array}$ & $\begin{array}{l}1 \\
2 \\
2 \\
2\end{array}$ & $\begin{array}{l}- \\
-\end{array}$ & $\begin{array}{l}- \\
- \\
-\end{array}$ & - & 9 \\
\hline
\end{tabular}

In $\mathrm{SO}_{3}{ }^{2-}$ (cf. Fig. 3: IV), the lone electron pair of sulphur will cause a decrease in bonding strength and the $\mathrm{S}-\mathrm{O}$ bond distances in $\mathrm{SO}_{3}{ }^{2-}$ will consequently increase from those in $\mathrm{SO}_{4}{ }^{2-}$. When an $A-\mathrm{S}$ bond exists (Fig. 3: I and III), two cases are possible. Consider first the case in which the $A$ atom is electronegative as oxygen or carbon. If the $A$ atom only can form a Acta Chem. Scand. 26 (1972) No. 1 
pure single bond with sulphur, as for instance in $\mathrm{K}_{2}\left[\mathrm{CH}_{2}\left(\mathrm{SO}_{3}\right)_{2}\right]$, ${ }^{12}$ the $3 d$ orbitals of sulphur are shared with only three oxygen atoms and the $\mathrm{S}-\mathrm{O}$ distances will decrease from the distances found for $\mathrm{SO}_{4}{ }^{2-}$. However, if the $A$ atom is less electronegative than oxygen, i.e. the bond has a rather high ionic character, the effect of the lone electron pair is reduced, and the $\mathrm{S}-\mathrm{O}$ distances will be shorter than found for the $\mathrm{SO}_{3}{ }^{2-}$ group, but longer than in $\mathrm{SO}_{4}{ }^{2-}$. When the oxygen atoms have ligand atoms rather close, Fig. $3: \mathrm{V}$, the effect of the $\pi$ bonding will be reduced by interaction with the oxygen atoms and the $\mathrm{S}-\mathrm{O}$ distances will increase from those of $\mathrm{SO}_{3}{ }^{2-}$.

In summary, the $\mathrm{S}-\mathrm{O}$ bond lengths increase in the order

$$
\left[A-\mathrm{SO}_{3}\right]^{-} \rightarrow \mathrm{SO}_{4}{ }^{2-} \rightarrow A^{\mathrm{n}+} \cdots \mathrm{SO}_{3}{ }^{2-} \rightarrow \mathrm{SO}_{3}{ }^{2-} \rightarrow \mathrm{SO}_{3}{ }^{2-} \cdots X
$$

where $X$ represents oxygen, nitrogen and/or metal ion.

The materials listed in Table 1 give several instances of bonding between the sulphur and non-oxygen atoms. Clear evidence of the influence of additional bonding to the sulphur on the $\mathrm{S}-\mathrm{O}$ distance is given by the structure of $\mathrm{K}_{2}\left[\mathrm{CH}_{2}\left(\mathrm{SO}_{3}\right)_{2}\right]^{12}$ Here the "sulphite" oxygen atoms are unaffected by supplementary bonding and the $\mathrm{S}-\mathrm{O}$ distances (average $1.46 \AA$ ) being below the one of $\mathrm{Na}_{2} \mathrm{SO}_{3}$ by several hundredths of an Angström unit and $0.01 \AA$ below the one of $\mathrm{SO}_{4}{ }^{2-}$ in concordance with the $\mathrm{S}-\mathrm{O}$ distance expected for $\mathrm{ASO}_{3}{ }^{-}$ compounds. For the sulphonate compound the $\mathrm{O}-\mathrm{S}-\mathrm{O}$ angle considerably exceeds the tetrahedral value.

Several metal sulphites referred to in Table 1 furnish evidence of bonding between sulphur and metal atoms with a tetrahedral coordination around sulphur comprising in addition to the metal atom the three sulphite oxygen atoms. The influence on the $\mathrm{S}-\mathrm{O}$ distance by this bonding is, however, not immediately obvious in any of the substances quoted since bonding effects are also exerted on the $\mathrm{O}$ atoms (Fig. 3: III and V). Thus, in $\mathrm{Ag}_{2} \mathrm{SO}_{3},{ }^{4}$ the two $\mathrm{Ag}$ atoms are crystallographically non-equivalent. One of the Ag atoms belongs in the tetrahedron surrounding the $\mathrm{S}$ atom, while the other is bonded exclusively to oxygen atoms. The effects of the $\mathrm{Ag}$ atoms on the $\mathrm{S}-\mathrm{O}$ bond distance thus counteract each other and the average $\mathrm{S}-\mathrm{O}$ distance is rather close to the one present in $\mathrm{Na}_{2} \mathrm{SO}_{3}$. Even more complicated schemes of bonding are found in the copper sulphites $\mathrm{NH}_{4} \mathrm{CuSO}_{3}{ }^{1}$ and $\mathrm{Cu}_{2}{ }^{\mathrm{I}} \mathrm{Cu}^{\mathrm{II}}\left(\mathrm{SO}_{3}\right)_{2} \cdot 2 \mathrm{H}_{2} \mathrm{O}^{2}$ The monovalent $\mathrm{Cu}$ atoms of the former have a tetrahedral environment comprising one $\mathrm{S}$ and three $\mathrm{O}$ atoms and are likely to affect both these kinds of atoms. It should be noted, however, that the $\mathrm{Cu}-\mathrm{S}$ distance $(2.15 \AA)$ is very short, exceeding the $\mathrm{Cu}-\mathrm{O}$ distance by only $0.03 \AA$. This may be compared with the $\mathrm{Cu}-\mathrm{S}$ distance $2.32 \AA$ in $\mathrm{CuFeS}_{2} .{ }^{13}$ The influence of $\mathrm{Cu}$ on the $\mathrm{O}$ atoms may thus be comparatively low. However, the latter are also linked by hydrogen bonding to nitrogen atoms. The effect of this bonding scheme results in an $\mathrm{S}-\mathrm{O}$ bond distance not very different from the value found in $\mathrm{Na}_{2} \mathrm{SO}_{3}$. The structure of the copper sulphite, $\mathrm{Cu}_{2}{ }^{\mathrm{I}} \mathrm{Cu}^{\mathrm{II}}\left(\mathrm{SO}_{3}\right)_{2} \cdot 2 \mathrm{H}_{2} \mathrm{O}$ containing both mono- and divalent metal, is characterized by a bonding scheme similar to, but more complicated than that of $\mathrm{NH}_{4} \mathrm{CuSO}_{3}$.

The sulphite $\mathrm{O}$ atom would be rather strongly affected by participation in hydrogen bonding (Fig. 3: V). The effect is illustrated by a comparison of $\mathrm{Na}_{2} \mathrm{SO}_{3}$ on the one hand and $\mathrm{NiSO}_{3} \cdot 6 \mathrm{H}_{2} \mathrm{O}^{14}$ and $\left(\mathrm{NH}_{4}\right)_{2} \mathrm{SO}_{3} \cdot \mathrm{H}_{2} \mathrm{O}^{35}$ on the other. 
Both of the latter exhibit distances between the sulphite oxygen atoms and water molecule oxygens or ammonium nitrogens indicative of strong hydrogen bonds ( $c f$. Table 2). The average $\mathrm{S}-\mathrm{O}$ distances of the latter compounds are

Table 2.

\begin{tabular}{|l|c|c|c|c|c|}
\hline $\begin{array}{l}\text { Type of S-O } \\
\text { compound }\end{array}$ & $\mathrm{MSO}_{3}{ }^{-}$ & $\mathrm{SO}_{4}{ }^{2-}$ & $\mathrm{M}^{n+} \mathrm{SO}_{3}{ }^{2-}$ & $\mathrm{SO}_{3}{ }^{2-}$ & $\mathrm{SO}_{3}{ }^{2-} \ldots \mathrm{X}$ \\
\hline Compound & $\mathrm{K}_{2}\left[\mathrm{CH}_{2}\left(\mathrm{SO}_{3}\right)_{2}\right]$ & $\mathrm{Li}_{2} \mathrm{SO}_{4} \cdot \mathrm{H}_{2} \mathrm{O}$ & $\begin{array}{c}\mathrm{Co}(\mathrm{en})_{2} \mathrm{SO}_{3} \cdot \\
\mathrm{NCS}_{2} \cdot \mathrm{H}_{2} \mathrm{O}\end{array}$ & $\mathrm{Na}_{2} \mathrm{SO}_{3}$ & $\mathrm{NiSO}_{3} \cdot 6 \mathrm{H}_{2} \mathrm{O}$ \\
$\begin{array}{l}\text { Average } \mathrm{S}-\mathrm{O} \\
\text { distance }\end{array}$ & $1.461 \AA$ & $1.472 \AA$ & $1.485 \AA$ & $1.504 \AA$ & $1.536 \AA$ \\
Reference & 12 & 9 & 17 & 3 & 14 \\
\hline
\end{tabular}

1.524 and $1.536 \AA$, each significantly longer than the values found in the $\mathrm{Na}_{2} \mathrm{SO}_{3}$ structure.

In $\mathrm{PdSO}_{3}\left(\mathrm{NH}_{3}\right)_{3}{ }^{16}$ the metal atom has an approximately square environment comprising the $\mathrm{S}$ atom and three $\mathrm{N}$ atoms. There is no Pd-O bonding and the metal atom should thus only exert a shortening effect on the $\mathrm{S}-\mathrm{O}$ distances. This is, however, somewhat opposed by the presence of weak hydrogen bonds between $\mathrm{O}$ and $\mathrm{N}$ atoms. The resulting distance is $0.01 \AA$ less than the one in $\mathrm{Na}_{2} \mathrm{SO}_{3}$. The angles at the $\mathrm{S}$ atom are quite close to the ideal tetrahedral value. The bonding scheme is rather similar in $\mathrm{Co}(\mathrm{en})_{2} \mathrm{SO}_{3} \cdot \mathrm{NCS}_{2} \cdot 2 \mathrm{H}_{2} \mathrm{O} \cdot{ }^{17}$ The Co atom is bonded to the $\mathrm{S}$ atom but not to the $\mathrm{O}$ atoms of the sulphite groups. The latter are linked by hydrogen bonds to $\mathrm{N}$ or water $\mathrm{O}$ atoms.

The structural data now available thus seem to be in concordance with the ideas proposed above to explain the variation of the $\mathrm{S}-\mathrm{O}$ distances in various sulphur-oxygen compounds. However, it should be emphasized that the effects on bond lengths and angles are rather small and often within the estimated standard deviations of the experimentally derived data. Further discussions along these lines would require very accurate structural data from representative metal sulphites.

Acknowledgements. The investigation has received financial support from the Swedish Natural Science Research Council and from the Tri-Centennial Fund of the Bank of Sweden.

The authors wish to thank Professor Arne Magnéli for his encouraging interest. We are also indebted to Dr. Don F. Koenig for correction of the English of this paper.

\section{REFERENCES}

1. Kierkegaard, P. and Nyberg, B. Acta Chem. Scand. 19 (1965) 2189.

2. Nyberg, B. and Kierkegaard, P. Acta Chem. Scand. 22 (1968) 581.

3. Larsson, L. O. and Kierkegaard, P. Acta Chem. Scand. 23 (1969) 2253.

4. Larsson, L. O. Acta Chem. Scand. 19 (1969) 2261.

5. Zachariasen, W. H. and Buckley, H. E. Phys. Rev. 37 (1931) 1295.

6. Wells, A. F. Structural Inorganic Chemistry, Oxford University Press, London 1962, p. 432. 
7. Gillespie, R. J. and Robinson, E. A. Can. J. Chem. 41 (1963) 2074.

8. Robinson, E. A. Can. J. Chem. 42 (1964) 1494.

9. Larson, A. C. Acta Cryst. 18 (1965) 717.

10. Baur, W. Acta Cryst. 17 (1964) 1361.

11. Cruickshank, D. W. J. J. Chem. Soc. 19615486.

12. Truter, M. R. J. Chem. Soc. 19623393.

13. Strukturbericht 2 (1932) 48.

14. Baggio, S. and Becka, L. N. Acta Cryst. B 25 (1969) 1150.

15. Batelle, L. F. and Trueblood, K. N. Acta Cryst. 19 (1965) 531.

16. Spinnler, M. A. and Becka, L. N. J. Chem. Soc. 19671194.

17. Baggio, S. and Becka, L. N. Acta Cryst. B 25 (1969) 946.

Received April 21, 1971. 